Article

\title{
Analysis Factors Related to Implementation of Complete Basic Immunization in Work Area of Pengambiran Public Health Center in Padang 2017
}

\author{
Ade Nurhasanah Amir ${ }^{1}$, Eryati Darwin ${ }^{2}$ Yuniar Lestari ${ }^{3}$ \\ 1Master of Master Degree Program in Midwifery Faculty of Medicine University of Andalas \\ 2Section of Histology Faculty of Medicine Andalas University \\ 3 Nutrition Department Faculty of Medicine Andalas University
}

SUBMISSION TRACK

Recieved: 20Juni 2018

Final Revision: 25 Juni 2018

Available Online: 30 Juni 2018

\section{KEYWORDS}

Basic Immunization, Toddler

CORRESPONDENCE

Phone: 085274832282

E-mail: adhek_nurhasanahamir@yaho.com

\section{A B S T R A C}

The role of a mother in the immunization program is very important, so their understanding of immunization is necessary, the behavior of a person or society about health is determined by knowledge, attitude, belief, tradition, work etc. from the person or society concerned. In addition, the availability of health care facilities, attitudes, behavior of health workers on the provision of health information will also support and strengthen the formation of health behaviors, This study aims to determine the factors that affect the provision of complete basic immunization, This study uses a combined research method between quantitative and qualitative.Sample for this study is 107 mother mother, while informant for qualitative study is Head of PuskesmasPengambiran Padang City, Responsible, Immunization Officer of Puskesmas and Kader which is in Working Area of PengambiranPublic Health in Padang City, The result of this study shown that family support is the most important factors in the implementation Complete basic immunization $(p=0.001)$. The results of the analysis revealed that the coverage of the implementation of complete basic immunization has not been successful because the lack of active role of cadres and health officers in community in informing immunization in depth. so that there is still a lack of understanding from mothers and families which has no family support in the implementation of complete basic immunization, it has not reached $95 \%$ target because the system implementation of complete basic immunization services that have not been optimal. It needs various efforts to improve the achievement of complete basic immunization coverage especially through optimizing the role and function of health and cadre officers and optimizing partnerships with various parties. 


\section{INTRODUCTION}

Health development aims to improve public health status in order to improve the quality of life, intelligence and community welfare (1). This is then outlined in the Millennium Development Goals (MDGs) which is a global and national commitment to improve the welfare of the people, one of the goals of the MDGs is to reduce child mortality with a target of reducing child mortality under five years by two-thirds in the period from 1990 to 2015 means that it decreases from 97 per 1000 live births to 32 per 1000 live births (1). The fact that the level of health is still low especially in the poor reflected from the high AKI and IMR, this is influenced by the lack of clean and healthy life behavior has not been entrenched in people who have knowledge and education is still low ${ }^{2}$.

Efforts to reduce infant and under-five mortality include improving healthy behaviors, as well as concerns about child survival and early development, and increasing immunization coverage (3). Accelerating the decrease of under-five mortality rate by government is one of them is immunization program which is promotive and preventive activity that have important role in decreasing infant and child mortality 4

Over the past few years, concerns about the return of some infectious diseases and the rise of new infectious diseases are increasing (5). $(30 \%)$, the incidence of malnutrition, not $100 \%$ of UCI National Village, the incidence of measles, varicella and polio cases. With the focus of intervention, among others, Quality Improvement and Quantity of health personnel are expected to decrease the number Neonatal death ${ }^{2}$

The success of infants in obtaining five basic immunization types (HB0, BCG, DPT$\mathrm{HB}$, Polio, and Measles) was measured through a complete basic immunization indicator, compared to the 2008-2011 period, the coverage of complete basic immunization during 2012-2015 in Indonesia decreased (6
). The full coverage of basic immunization based on routine data in 2010-2013 reaches the target of the Ministry of Health's Strategic Plan (Renstra), but by 2014 and 2015 immunization coverage does not reach the target of the Renstra expected ${ }^{6}$. There is still a perception in the community and even in the household that infant immunization and weighing are not important to be a challenge to the success of the health program ${ }^{2}$. Research in Bandung shows that there is relationship of mother characteristic of under five $(63,4 \%)$ and mother perception of toddler to immunization $(64,8 \%)$ to complete basic immunization implementation ${ }^{7}$.

The number of infant deaths in West Sumatra Province as many as 681 people spread in 19 districts / cities with the highest death contributor from the city of Padang as many as 108 people. The number of deaths of children under five in West Sumatera are 856 people spread in 19 districts / cities with the highest death contributor from Padang City as many as 125 people ${ }^{(8)}$. Research in the field of 2017 shows high infant mortality caused by several factors: maternal factors, infant factors, and health services. Maternal factors include social, low education, knowledge of health services and low economic levels, age less than 20 years or over 35 years. Toddlers, especially infants are a group of highly vulnerable populations with infections and disease attacks due to the development of organs and immune systems that have not been maximized. This condition causes many babies to die from illnesses that are not handled properly.1-3 Infant mortality refers to the death of a child under one year of age ${ }^{(9)}$.

Baby target 0 - 11 months in 2014 is 102,040 babies. Achievement of Immunization program of west sumatera province in 2014 there are still some that have not been reached ${ }^{(8)}$. Program Outreach is seen from first contact immunization coverage, $\mathrm{Hb} 0$ : $86.62 \%$, BCG: $92.63 \%$, DPT-HB3: $86 \%$. Meanwhile, the first contact target in 2014 is $95 \%$. When compared to the 
achievement with the first contact target, no one has achieved the target, it is because there are still some people in myth community that illegal immunization, So for West Sumatera province in 2014 coverage complete basic immunization is still under the target of only $84.51 \%{ }^{(8)}$.

Based on the preliminary survey data conducted at the Padang City Health Office, the work area of puskesmaspengambiran is one of the lowest immunization coverage of 22 puskesmas in padang city, of 792 immunized infants got 66.6 percent (DKK, 2015). Based on these data it can be seen that PuskesmasPengambiran is the village with the lowest immunization coverage in 2015 with coverage of each immunization type as follows DPTHB1 (77,4\%), DPT-HB2 $(78,6 \%), \quad$ DPT-HB3 $(78,0 \%)$, polio4 $(73.3 \%)$, and measles $(71.2 \%)$. Based on these data, immunization coverage generally has not fulfilled the target of $\geq 80 \%$ ie DPT$\mathrm{HB}$, polio and measles ${ }^{(9)}$. So from that research interested to examine factor factor what related to completeness of basic immunization at baby in puskesmaspengambiran 2017 Based on the above description, the researcher is interested in taking the title of "Analysis of Factors related to Complete Basic Immunization of Infants in the Working Area of PuskesmasPengambiran 2017. The purpose of this research is to analyze Factors related to the implementation of complete basic immunization in the region work of puskesmas in Padang City

\section{METHOD}

The type of this research is combination research that is research method that combine quantitative research method and qualitative research method (9). Quantitative research uses cross sectional design. Data on independent variables and dependent variables are collected and assessed at a time. Then qualitative research is conducted to dig deep information about the effort of complete basic immunization management for the implementation of complete basic immunization in infant year 2017. This research was conducted in Working Area of PuskesmasPengambiran Padang City. with research time in July-November 2017. The population in this study is all mothers who have under-fives under 2 years in the working area of PengambiranPuskesmas which is about 292 people. Sampling was taken with multistage random sampling technique. Multistage random sampling technique is a sample selection technique that is done in stages and usually based on the division of work area of a government. Inclusion criteria Infant mothers who have KMS or immunization records in infants, mothers who have babies 12-24 months, Mothers willing to be respondents, the number of research samples as many as 107 people. The data were collected by interview using questioner and observation / study of KIA book document, univaiat, bivariate and multivariate analyzed data.

\section{RESULT}

Puskesmas in Padang as many as 22 puskesmas.PuskesmasPengambiran is one of the community health centers with low coverage of basic immunization with only $60 \%(8 \%)$, Batuang Village taba. The working area of Pengambiran Public Health Center is $27.21 \mathrm{~km} 2$ with the northern boundary with Tanjungsaba, the south is bungus bay of sack, east of Lubuk refinery in the east, South Padang subdistrict ${ }^{(8)}$

Facilities and infrastructure owned by PuskesmasPengambiran consisted of 1 primary health center, 1 sub health center, 4 units of poskeskel, 1 unit of mobile health center, 46 posyandubalita, 10 posyandu elderly, 187 cadres, 6 private doctors practice, 17 practice of private midwife ${ }^{(8)}$. While there are 17 Posyandubailita, 1 posyandu elderly, 7 private practice midwives, and 1 maternity hospital, in Pampangan sub-district there are 9 posyandubalita, 2 posyandu elderly, 4 independent midwives, 1 private practice physicians, BatuangTaba urban village have 9 posyandubalita, 3 posyandu elderly, 3 midwives of independent practice, and 1 
maternity house, in kampuangjua village there are posyandubalita as many as 4 pieces, 2 posyandu elderly, 3 midwives of independent practice, and 1 maternity Hospital. and lastly in Kelurahan Gates there are posyandu toddlers as many as 7 pieces, posyandu elderly 2 fruit, and maternity house 2 pieces ${ }^{(8)}$

\section{Univariat Analysis Dependen Variabels}

Table 5.1 Frequency Distribution of Respondents Implementation of Complete Basic Immunization in Working Area of PuskesmasPengambiran Padang City Year 2017

\begin{tabular}{lll}
\hline Basic Immunization & $\mathrm{F}$ & $\%$ \\
\hline Incomplete & 53 & 49,5 \\
Complete & 54 & 50,5 \\
\hline Total & 107 & 100 \\
\hline
\end{tabular}

Based on table 5.1 it is seen that 53 respondents $(49.5 \%)$ of respondents did not carry out complete basic immunization in PuskesmasPengambiran Padang working area.

\section{Independent Variables}

Frequency Distribution of Respondents in the Working Area of PuskesmasPambambiran Padang City Year 2017

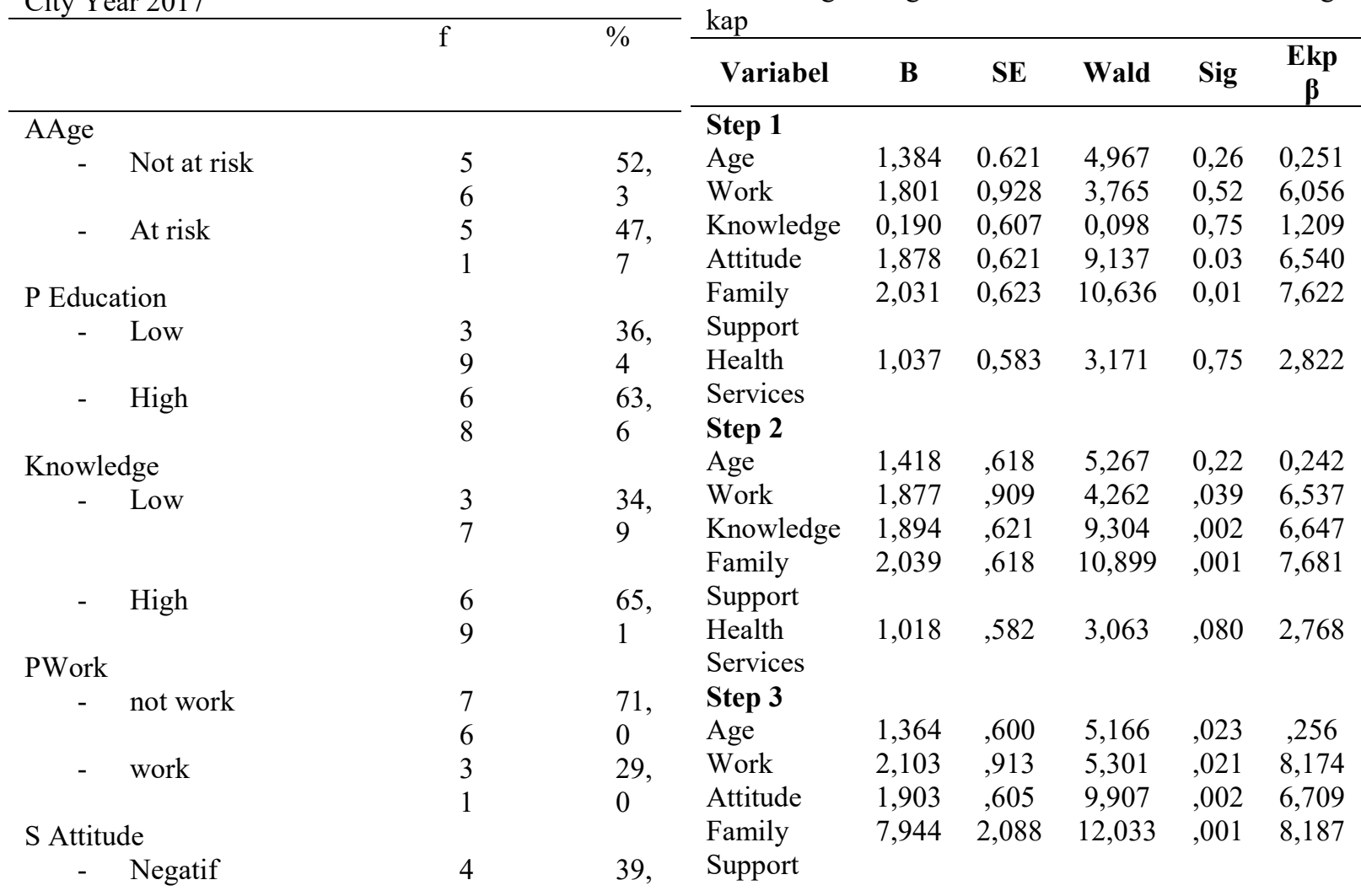

From table it can be seen that more than half the age range of complete basic immunization at age is not at risk, more than half of respondents have higher education, more than half of respondents have high knowledge, more than half of respondents are mothers who do not work, more than half of respondents have positive attitude, more half not getting family support. andcurameng from half get unfavorable services.

The result of bivariate analysis shows that not all variables have $\mathrm{p}$ value $<0.25$. Variables that enter into multivariate are age, job, attitude, family support and health services.

Tabel 5.11 AnalisisFaktor Paling Dominan yang BerhubungandenganPelaksanaanImunisasiDasarLeng 
The results of the analysis in the table shows that the variable age, occupation, attitude, family support is the dominant factor on the implementation of basic immunization complete with $p<0.05$. To see which variable has the greatest effect on independent variables, seen from exp (B). The greater the value of $\exp (\mathrm{B})$ means the greater the effect on the dependent variable. The largest exponential betha $(\exp B)$ value of the family support variable is 8.187, meaning that if family support can be applied properly then the implementation of complete basic immunization is 8 times better.

\section{Qualitative Research Results}

Qualitative data collection was conducted using in-depth interviews and focus group discussions (FGDs). In-depth interviews were conducted to the heads of puskesmas, immunization managers, immunization officers, cadres. FGD Conducted on 10 Mothers who have children under five in the working area of PuskesmasPengambiran Padang. FGD was conducted to the respondents who had previously filled out the questionnaire in this study. Informants in this study amounted to 14 people.

\section{Characteristics of Informants}

Table 5.12 Characteristics of Informants in Implementation of Complete Basic Implementation in Working Area of PuskesmasPengambiran Kota Padang

\begin{tabular}{|c|c|c|c|c|c|}
\hline $\begin{array}{l}\text { Informa } \\
\text { n }\end{array}$ & $\begin{array}{l}\text { Init } \\
\text { ial }\end{array}$ & $\begin{array}{l}\text { A } \\
\text { ge }\end{array}$ & $\begin{array}{l}\text { Backg } \\
\text { roud }\end{array}$ & $\begin{array}{l}\text { Educa } \\
\text { tion }\end{array}$ & Method \\
\hline 1 & DN & 40 & $\begin{array}{l}\text { Health } \\
\text { Of } \\
\text { Public } \\
\text { center }\end{array}$ & S1 & $\begin{array}{l}\text { Deepthint } \\
\text { erview }\end{array}$ \\
\hline 2 & $\mathrm{~S}$ & 30 & $\begin{array}{l}\text { Public } \\
\text { center }\end{array}$ & S1 & \\
\hline 3 & ES & 33 & $\begin{array}{l}\text { Public } \\
\text { center }\end{array}$ & S1 & \\
\hline 4 & EA & 40 & Kader & SMA & \\
\hline 5 & RK & 35 & Mother & SMA & \\
\hline 6 & E & 21 & Mother & SMA & \\
\hline
\end{tabular}

\begin{tabular}{lllll}
\hline $\mathbf{7}$ & RS & 22 & Mother & \\
& & & & SMA \\
$\mathbf{8}$ & J & 28 & Mother & \\
& & & & SMA \\
\hline $\mathbf{9}$ & S & 34 & Mother & \\
& & & & SMA \\
\hline $\mathbf{1 0}$ & SI & 29 & Mother & \\
& & & & SMA \\
\hline $\mathbf{1 1}$ & AN & 31 & Mother & \\
& P & & & SMA \\
\hline $\mathbf{1 2}$ & AN & 35 & Mother & \\
& Y & & & SMA \\
\hline $\mathbf{1 3}$ & DK & 27 & Mother & \\
& & & & SMA \\
\hline $\mathbf{1 4}$ & AJ & 27 & Mother & \\
& & & & SMA \\
\hline
\end{tabular}

\section{DISCUSSION}

\section{Age}

Based on the results of the study found more than half the age range of the implementation of complete basic immunization at age not at risk as much as $52.3 \%$.

The results of this study are similar to those of ViviTriana (2015), found that out of 80 respondents, $55(68.75 \%)$ of respondents with age range of complete immunization at age not at risk (10)

This research is not in line with research conducted by Rizani (2009), which states there is no significant relationship between maternal age and mother's behavior in immunization. so age can not be said to be a risk factor in providing meaningful immunization between age and complete immunization of infants (11)

Physically and mentally the mother who gives birth under the age of 20 is not ready to take her pregnancy and the young mother is not ready to care, nurture and raise her baby. In contrast, women over 35 years of age will more often face difficulties during pregnancy and at the time of childbirth and will affect the survival of her baby. Young mothers usually have new children who tend to pay more attention to their children including basic immunization. Meanwhile, elderly mothers usually have more than one child and have more activity that affect mother's motivation to bring their child to health 
service to get basic immunization.

From the results of FGDs with infant mothers in the Working Area of PuskesmasPengambiran Padang city obtained information that the obstacle of baby mother related to mother age is the willingness of time to bring baby to posyandu. Ratrata respondents need more than 1 hour to get immunization service and return home. In general, mothers who are older than 35 years old have been lazy to wait long at posyandu and also because at this age mother has many responsibilities to other children. This is in accordance with information obtained from FGDs with the responses of under-fives and in-depth interviews with health workers. According to health workers usually pay more attention to basic immunization in infants is in young mothers or newly married couples and new children, ranging from 20-35 years. While the age of respondents over 35 years has been difficult to invite to posyandu (11)

Based on the description above, it can be seen that more than half of respondents who implement complete basic immunization in the age range are not at risk. The results of the study found that community and health worker preparations are still poor. These results were found after the researchers conducted direct observation of the KMS book on the implementation of immunization attached in the KIA book. it is difficult to get to posyandu (11)

After observing the KMS, many respondents in the age range are at risk of not conducting complete basic immunization to their babies. The figure shows that community preparation and planning for immunization implementation is not good enough.

According to the researcher's assumption, if the planning and preparation of the implementation of complete basic immunization is done in accordance with the expected health personnel actually have made promotive and preventive efforts as the main goal of Puskesmas, especially in preventing infectious diseases in infants and toddlers.

\section{Work}

Based on the results of the study found most of the respondents complete basic immunization implementation on working mothers.

The results of this study are in accordance with the theory put forward by AnoragaPandji (2005) which states that increasing the breadth of employment, increasingly encouraging the number of women who work, especially in the private sector. On the one hand it has a positive impact on income growth, but on the other hand it has a negative impact on the development and maintenance of children. The relationship of maternal employment status to the completeness of basic immunization in infants is that if the mother works to earn a living, it will decrease the opportunity or time to come to the immunization service, so that will result in the child will not get the completeness of basic immunization.

FGD results with the respondents in the working area of PuskesmasPengambiran Padang related to working mothers who do not implement complete basic immunization is the problem of time of complete basic immunization in posyandu coinciding with respondent working hours so that respondent can not deliver their baby to posyandu to implement complete basic immunization. According to health officials, many working mother babies do not come during basic immunization at posyandu, where babies living with caregivers or grandmothers do not dare to take immunization action if health workers come to the homes of working mothers.

According to the researcher's assumptions, if the planning and preparation of the implementation of complete basic immunization is done as expected then health personnel actually have made promotive and preventive efforts as the main purpose of puskesmas, especially in preventing infectious diseases in infants and toddlers. Respondents already familiar with the implementation of complete basic immunization will still provide complete 
basic immunization to their babies by balancing working time.

\section{Attitude}

Based on the result of the research, most of the respondents of the implementation of basic immunization have negatife attitude.

The results are in line with the results of research Paridawati (2013). In the study showed that attitudes have a role to the basic immunization.

The study findings are not in line with the research of Febriana (2009), the research shows that the attitude does not affect the completeness of basic immunization. Approximately $81.58 \%$ of parents belong to a good attitude, but the good attitude is not followed by the high number of immunization completeness which only reached $46.78 \%$.

Based on FGD results and in-depth interviews with respondents who have children with an incomplete immunization status who are mostly sociocultural or beliefs that assume that immunization is unnecessary. Respondents with socioculture or beliefs tend to have negate attitudes towards immunization, so that many of the immunization status of their children is incomplete and does not even immunize. Besides the misunderstanding of the community about the side effects of immunization also greatly affect the attitude of the community against immunization (12)

Attitude is an internal reaction of a person who is influenced by various factors of personal experience, culture, other important people, religion and emotional factors in the individual who has an important role in the formation of attitudes. The process of attitudes caused by stimuli such as public knowledge. Such stimuli stimulate society to respond in the form of positive attitudes and negative attitudes that will eventually be realized in the form of concrete actions (13)

Attitudes consist of 4 levels of receiving, individuals wanting and paying attention to stimuli given, responding (responding), individual attitudes can provide answers when asked, doing and completing tasks assigned, valuing; the attitude of the individual invites other people to work on or discuss a problem, and responsible (responsible), the individual's attitude will be responsible and ready to bear all the risks of everything he chooses (13.12). In-depth interviews with health workers show that respondents have a child with an incomplete immunization status that is mostly a sociocultural society or a belief that immunization is haram / should not be given to a baby, assuming immunization can lead to a child's fever, and not agreeing that the immunization is very important for the child, it is known that immunization is very important for children. The effects of fever perceived by children are a temporary effect of the immunization because of the influence of immunization vaccines that are incorporated in the child's body, as well as the assumption of immunization, since vaccines given at immunization are not prohibited in religion. Respondents with social culture or beliefs tend to have negative attitudes towards immunization, so many children do not get complete basic immunization.

According to the researcher's assumption the respondent's attitude in this research covers the comfort of the mother when the child is immunized, the mother's comfort after the child is immunized, the mother's attitude about the effect of immunization, religious view (halal / haram) of immunization. Factors that affect the number of respondents who have negative attitudes about immunization is a low knowledge of immunization, the lower the mother's knowledge of immunization will contribute greatly to the formation of a bad attitude / negative about immunization, someone who already knows the truth about a thing then they will also have a positive attitude towards it, as well as immunization. The formation of this attitude is also inseparable from others who are considered important, mass media, emotional factors of the individual and pengalamam about 
immunization. Preparation and implementation of complete basic immunization should be supported by a maximal role of health, cross-sector and community health officials, negative attitudes from the community about immunization need to be improved so that future generations can avoid certain infectious diseases, what can be done is to equate perceptions about the implementation of immunization with increasing public awareness of the importance of immunization, the side effects of immunization and the content of immunization vaccines given to infants. This is done in the hope that there is no presumption that immunization is not important, immunization is forbidden / forbidden

\section{Healthservices}

Based on the results of the study found more than half of respondents implementing complete basic immunization to get services that are less good. The results of this study are in line with research conducted by Rahmawati stating that officers who are always present at the time of immunization services (95\%) more respondents who carry out complete basic immunization from officers who are not present during immunization schedule, as well as service officers who serving the mother and baby, the friendly officer (95\%) is more likely to carry out complete basic immunization than the unhelpful officer while serving the respondent (mother and baby).

Health services are jointly or jointly organized within an organization to maintain and improve health, prevent and cure disease and restore the health of individuals, families, groups and even communities (14)

From the FGD results with the respondents in the Working Area of PuskesmasPengambiran Padang City related to the health service that for some health workers who have given information and invite to complete the complete basic immunization, the respondent will come to posyandu, and for those who do not get the information and solicitation immediately sometimes forget to come to posyandu.

According to health officials who do not come during posyandu usually we visit oneone house after completion of posyandu whose baby is at home at the time of posyandu implementation.

According to the researcher's assumptions, the better the health service provided by the health worker then this will have an impact on the increase of health degree, as well as the immunization, the better the immunization service obtained by the parents and the baby, the greater the coverage of complete basic immunization, this is derived from the preparation of health workers from the outset who approached the community by equating perceptions about complete basic immunization and not free from the high willingness of the community towards the implementation of complete basic immunization.

\section{b. Multivariate Discussion}

The result of the research on bivariate selection found 4 variables that will be candidate in the next test that is regression test where the variable is age, occupation, attitude, and family support.

After double logistic regression test, the most related variable to the implementation of complete basic immunization is family support variable with $p=0,001$

In multivariate analysis results can be concluded that if respondents get positive family support in the implementation of complete basic immunization it will contribute to the achievement of the implementation of complete basic immunization of 8 times better.

The results of this study are relevant to Sri Enda Sitepu (2012) research, which states that there is family support (husbands, parents, in-laws and other relatives) to 
mothers in the form of getting information from families about basic immunization in children. Mom will feel that immunization is very important to boost her baby's immunity. This condition will certainly greatly affect the achievement of the expected immunization. Mothers who are supported by family members to immunize their children tend to provide complete basic immunization to their children, otherwise mothers who are not supported by family members to immunize their children have a risk of not providing complete basic immunization to their children. The results of this study in accordance with the theory that states that to realize the attitude into a real action required support factors or a condition that allows, among others, the facility. A positive mother's attitude to immunization should be confirmed by her husband and family, there is an easily accessible immunization facility, so that the mother may immunize her child (14)

From the FGD results with the respondents in the Working Areas of PuskesmasPengambiran Padang obtained information that family support greatly affects the implementation of complete basic immunization because if the family does not approve then the mother also does not implement complete basic immunization. Mothers who give birth and have children receive decisions made by husband and family. According to health workers based on in-depth interviews, it is found that there is a myth in the family itself which states that immunization in religion and immunization is not good for the baby, because it will cause the baby to become fever after immunization, so the implementation of immunization in infants is not done by the mother.

Officers provide a letter of agreement that can be accountable to the Department of Health if there is a family that does not conduct complete immunization.

Family support is the support provided by family members (husbands, wives, and relatives) so that individuals who are given support feel that they are cared for, valued, getting help from meaningful people and have strong family ties with other family members (Lubis, Namora\&Hasnida, 2009). Individuals who receive high family support will be more optimistic individuals in dealing with health and life issues and more skilled in meeting psychological needs (2) According to the researchers' assumptions on the results of the relationship obtained in this study, in general mothers who do not get good family support caused by the myths dikeluarga itself that states that immunization is illegal in religion and immunization is not good for the baby, because it will cause the baby to be febrile after immunization, the implementation of immunization in infants is not performed by the mother.

\section{CONCLUSION}

The coverage of complete basic immunization has not reached $95 \%$ target because the system of implementation of complete basic immunization service which not yet optimal. It needs various efforts to improve the achievement of complete basic immunization coverage, especially through optimizing the role and function of health and cadre officers and optimizing partnerships with various parties. 



\section{REFERENCES}

Azwar, Human Attitudes Theory and Measurement. Jakarta: PustakaPelajar 2008

Data and Information Center Ministry of Health RI.Immunization Situation in Indonesi. Jakarta 2016.

Health MO. Indonesian Demographic And Health Survey (IDHS). Jakarta: Ministry Of Health: 2007.

Lisnawati. Healthy Generation Through Immunization. Jakarta: Trans Info Media 2014; 5-14

Law of the Republic of Indonesia. RI Law No. 36 Jakarta: RinekaCipta 2009-5

Ministry of Health RI.Indonesia Health Profile 2014. Jakarta: Ministry of Health RI; 2015-

Notoatmodjo, Soekidjo. Health Promotion Theory \& Applications. Publisher PT AdiMahasatya: Jakarta 2010

Notoatmodjo, S. 2012. Health Research Methodology. Jakarta: RinekaCipta. Health Research Methodology. Jakarta: RinekaCipta. 2004

Priyoto. Changes in Health Behavior .. Yogyakarta: Graha Science 2015

Peshan Municipality of Padang City.Health Profile of Padang City 2015. Padang: Padang City Health Office 2016

Rustikayanti, Suryamah. Perceptions About Booster Immunization in Mothers with Children Under 24 Months. 5 June 2017. STIKes Dharma Husada Bandung Jl. Jakarta Canal No. 75 Antapani Bandung 2017

Rizani.factor factors related to mother's behavior in giving immunization 2011. Diploma thesis, 2009 andalas university

Sugiyono. Quantitative Research Methods, Qualitative and R \& D. Bandung: 2014; 21-28

Triana, vivi. Factors Associated with Complete Basic Immunization in Infants by 2015. University of Andalas. Padang

\section{BIOGRAPHY}

The first author is a midwife. He completed his midwifery diploma III education at the Ministry of Health Polytechnic of midwifery in 2010. Then he continued his diploma IV education for midwifery educators at the Ministry of Health Poltekkes in 2011 to complete it in 2012. In 2015 the author continued his education in postgraduate program in midwifery at the Faculty of Medicine Andalas University and successfully completed in 2018.

The second author is a lecturer at the Department of Public Health and Community Medicine, Faculty of Medicine, Andalas University. He has graduated as a Doctor of Medicine (MD), Faculty of Medicine, Andalas University, Padang, currently he is one of the favorite professors at Andalas University.

The third author has completed medical education at Unand. Then he continued his master's degree at Padjajaran University in Bandung. After that he continued his doctoral education at Andalas University Padang. He is currently a lecturer at the Department of Public Health and Community Medicine, Faculty of Medicine, Andalas University. He has graduated as a Doctor of Medicine (MD), Faculty of Medicine, Andalas University 